\title{
THE EFFECT OF PLANT GROWTH-PROMOTING BACTERIA ON THE DEVELOPMENT, YIELD AND YIELD COMPONENTS OF BREAD (TRITICUM AESTIVUM L.) AND DURUM (TRITICUM DURUM) WHEATS
}

\author{
SONKURT, M. ${ }^{1}-$ Çı Ğ, F. ${ }^{2 *}$ \\ ${ }^{I}$ The Agriculture and Rural Development Support Institution, Mardin, Turkey \\ ${ }^{2}$ Department of Field Crops, Faculty of Agriculture, Siirt University, Siirt, Turkey \\ *Corresponding author \\ e-mail: fatihcig@hotmail.com; phone: +90-533-777-1140 \\ (Received 26 $6^{\text {th }}$ Jan 2019; accepted $27^{\text {th }}$ Feb 2019)
}

\begin{abstract}
This study was carried out with 3 replications and 24 parcels according to randomized complete blocks trial design between 2017 and 2018 as two separate experiments. The study was planned to determine the effects of previously identified Stenotrophomonas maltophilia TV14B (phosphate solubilizing), Bacillus atrophaeus TV83D (nitrogen fixation), Bacillus-GC group TV119E (phosphate solubilizing), Cellulomonas turbata TV54A (nitrogen fixation) and combined effects of Bacillus atrophaeus TV83D and Bacillus-GC group TV119E on the development of Ceyhan-99 and Firat-93 bread wheat cultivars. According to the results, the highest grain yield for Firat-93 durum wheat cultivar was obtained under full dose chemical fertilizer application $(288.89 \mathrm{~kg} / \mathrm{da})$; while the highest grain yield $(283.33 \mathrm{~kg} / \mathrm{da})$ in the case of bacteria applications was observed with Bacillus atrophaeus TV83D, nitrogen-fixation bacteria. The difference between these two was not significant, and these bacteria can be seen as an alternative to chemical fertilization. The highest yield among bacterial applications was obtained under treatment with Bacillus atrophaeus TV83D, a nitrogen-fixation bacterium with 319.45 $\mathrm{kg} / \mathrm{da}$, and the difference between them was statistically significant. At the end of the study it was concluded that Bacillus atrophaeus TV83D bacterial strain can be used as a microbial fertilizer because of its ability to increase grain yield significantly in both genotypes.
\end{abstract}

Keywords: biofertilizer, diazotrophs, PGP activities, P-solubilization, sustainable production, wheat cultivars

\section{Introduction}

Cereals is a large group consisting of economically important species like the Graminea (wheats = corbels) family, cool climate cereals like wheat (Triticum), barley (Hordeum), oats (Avena), rye (Secale) and triticale, and warm climate cereals like corn (Zea), paddy (Oryza), maize (Sorghum), flint corn (Panicum) and avian (Phalaris) (Elçi et al., 1994). Wheat, corn and rice generate $85 \%$ of the world's grain production. Wheat is the most cultivated grain among these agricultural products providing high energy with grains containing plenty of starch. Wheat (Triticum sp.) is the most highly composite among cereals. Wheat is an indispensable plant used as a source of carbohydrates, providing basic input to livestock and industry. It is also the main food source of most countries with the largest cultivation area in the world.

Wheat constitutes approximately $29-30 \%$ of the world total grain production and is the most important plant-based protein source of humankind (Gustafson et al., 2009). Scientists consider its genetic complexity as a miracle, and which blends perfectly with changing environmental conditions. Wheat cultivars are the more superior in comparison with other grains and their nutritive values (Zohary and Hopf, 2000). 
Global efforts to increase wheat production in parallel with population growth have been partially successful. Although this has also increased the yield of wheat, it is not sufficient to meet the needs of the growing population.

As the aim in crop production is to increase the dry matter yield per unit area, intensive input use increases in parallel. Fertilizer is one of the most important items among these inputs. It is determined that approximately $15 \%$ of the total chemical fertilizer used in the world is in wheat farming. There is an increasing trend towards the use of organic fertilizers worldwide to avoid the negative effects of chemical fertilizer use. In these organic fertilizers, Plant Growth-Promoting Bacteria (PGPB) is an alternative source of microbial fertilizers. In researches, especially Pseudomonas ssp., Azospirillum sp. and Pantoea sp. bacteria groups were found to increase plant growth and nitrogen intake in wheat and maize grown in temperate climates (Meena and Rai, 2017).

In recent years, the commercial formulations of these bacteria have been used in the cultivation of many plants such as corn, wheat, potatoes and tomatoes and it has been determined that these bacteria have a significant effect on plant height, root development and increase in dry matter. In addition, the use of these bacteria is predicted to reduce the use, cost and environmental pollution of chemical fertilizers and pesticides (Mehnaz et al., 2001, 2010; Tozlu et al., 2014). It has been reported that bacterial activity varies according to soil properties, soil organic matter content, plant and bacteria variety and plant growing conditions (Çakmakçı et al., 2006). In this respect, further studies are needed on the effects of bacteria on plant growth. In this study, the effect of Plant Growth Inhibiting Bacteria on the development, yield and yield components of wheat were investigated. It has been determined that the effect of the bacteria, which are revealed by field and greenhouse studies especially on wheat, has not been investigated at an adequate level before. In this study, the bacteria, which are isolated from Van Lake Basin and known to promote plant growth, are inoculated in bread and durum wheat varieties. Afterwards, their effects on wheat yield, yield and yield components were investigated.

One of the aims of this study was to quantify the productivity of dryland farmed bread and durum wheat cultivars that was seed inoculated. In addition, the effect of these bacteria on reducing the use of inorganic fertilizers was also examined.

\section{Literature research}

In many countries, the effect of Plant Growth-Promoting Bacteria (PGPB) on durability against biotic and abiotic stress on yield increase in cereals has been extensively researched and will continue to be researched more. Studies conducted in different countries and ecologies show that PGPB significantly increased wheat yield parameters in single applications (Naveed et al., 2008; Zabihi et al., 2011; Hussain et al., 2016; Mukhtar et al., 2017; Sood et al., 2018; Tahir et al., 2018). In addition, it has been reported that biomass, grain yield, macro and micronutrient intake increased significantly compared to the control in studies where different bacteria were administered in multiple combination (Zabihi et al., 2011; Sood et al., 2018). In addition to the yield parameters of wheat, PGPB has been reported to increase the number of germination, increase in germination speed and germination rate (Rana et al., 2011; Laloo et al., 2017), increase the amount of capillary root (Dal Cortivo et al., 2017), increase the root length (Afzal and Bano, 2008; Abbasi et al., 2011; Dal Cortivo et al., 
2017), increase the height of the plant (Afzal and Bano, 2008; Abbasi et al., 2011; Mukhtar et al., 2017) and increase the root and body dry weight (Mukhtar et al., 2017). In addition, plant growth-promoting bacteria containing 1-Aminocyclopropane-1Carboxylate Deaminase (ACCD), which provides resistance to plant stress conditions, contribute to the growth and development of plants normally by reducing plant ethylene levels under various environmental stress conditions (Çakmakçı, 2009). In the study conducted with Indol Acetic Acid (IAA), siderefor, Hydrocyanic Acid (HCN) and ACC deaminase producing bacteria, germination rate and speed of the bacterium producing siderophore (Rana et al., 2011) was observed to increase. In addition, it has been reported that the bacteria with ACC deaminase activity have a significant increase in the yield parameters (Naveed et al., 2008).

It is aimed to reduce the amount of chemical fertilizers by using PGPB since chemical fertilizers cause significant environmental problems during and after their application to agriculture areas and also due to the use of intensive fossil fuels in their production. For this purpose, it was revealed in the studies conducted on wheat that the use of chemical fertilizers could be reduced by $20 \%$ to $50 \%$ with the usage PGPBs (Naveed et al., 2008; Zabihi et al., 2011; Abbasi et al., 2011; Hussain et al., 2016; Sood et al., 2018). In a study, it has been reported that PGPBs increase the yield of grain by $30-40 \%$ according to chemical phosphorous fertilization (Afzal and Bano, 2008).

\section{Materials and methods}

\section{Materials}

\section{Wheat species}

In this study, Firat-93 durum and Ceyhan-99 bread wheat varieties were used. Seeds were obtained from Seed Sales Office of General Directorate of Agricultural Enterprises. General characteristics of varieties are below.

Firat-93: Medium plant height, very waxy and strong stems; narrow, long and steep leaf structure. Spike is medium length, white in color and has black stringiness. It has a fuller, hard and glassy grain and its thousand grain weight is between $45-50 \mathrm{~g}$. It is suitable for summer, middle early and drought tolerant and has good tillering characteristics. It is recommended for rainy, irrigable areas and coastal areas of Southeastern Anatolia. It shows a tolerant reaction to yellow rust disease which can be seen from time to time in the region (Anonymous, 2018a).

Ceyhan-99: Plant height is between 90 and $100 \mathrm{~cm}$. The spikes are white and lengths are medium, and they are upright. It is resistant to bending. Grain color is white, and it has a hard structure. The weight of thousand grains varies between 41 and $45 \mathrm{~g}$. This wheat variety reacts well to fertilizers. Drought and winter resistances are moderate. It is resistant to yellow rust and Septoria diseases and it is half resistant to brown rust. Harvest-blending ability is high. The strings are not spilled at harvest time (Anonymous, 2018b).

\section{Bacteria strains}

The bacteria were isolated from the Van Lake basin with the TOVAG 1080147 TÜBİTAK project and their PGPB activity was detected (Erman et al., 2010). These bacteria were diagnosed with the microbial identification system (MIS) they were used as double combinations. These bacteria are: Stenotrophomonas maltophilia TV14B 
(phosphate solubilizing), Bacillus atrophaeus TV83D (nitrogen fixation), Bacillus-GC group TV119E (phosphate solubilizing), Cellulomonas turbata TV54A (nitrogen fixation) and Bacillus atrophaeus + Bacillus-GC group (TV83D + TV119E)

\section{Methods}

Climate and soil properties of the research site

The research was carried out in the laboratory of Field Crops Department of Agricultural Faculty of Siirt University in the period of 2017-2018 and in the trial area of Field Crops Department in dry agricultural conditions. The field trial was established at $37^{\circ} 58^{\prime} 2.18^{\prime \prime} \mathrm{K}$ and $41^{\circ} 51^{\prime} 13.10^{\prime \prime} \mathrm{D}$ coordinate point and 538 meters altitude.

In Siirt, terrestrial climate is dominant in general. Summers are hot and dry. The highest air temperature measured is $43.3{ }^{\circ} \mathrm{C}$ and the lowest air temperature is $-19.5^{\circ} \mathrm{C}$. The average temperature, precipitation and relative humidity values of Siirt, where the research was conducted are presented in Table 1. These values cover the long years (1938-2017) as well as the period between October-June 2017-2018. As can be seen from Table 1, the 2017-2018 production season was generally dry and the rate of rainfall in March and April decreased. However, the rainfall in the month of May has been $84.6 \mathrm{~mm}$ higher than the average of many past years (Anonymous, 2018c). This situation affected the wheat yield negatively.

Table 1. Average climate values of Siirt for long term averages in the past and for 20172018 October-June period

\begin{tabular}{c|c|c|c|c|c|c}
\hline \multirow{2}{*}{ Months } & \multicolumn{2}{|c|}{ Temperature $\left({ }^{\circ} \mathbf{C}\right)$} & \multicolumn{2}{c|}{ Precipitation $(\mathbf{m m})$} & \multicolumn{2}{c}{ Humidity (\%) } \\
\cline { 2 - 7 } & LTA* & $\mathbf{2 0 1 7 - 1 8}$ & LTA* & $\mathbf{2 0 1 7 - 1 8}$ & LTA* & $\mathbf{2 0 1 7 - 1 8}$ \\
\hline October & 17.9 & 18.4 & 49.1 & 5.4 & 50.3 & 34.6 \\
November & 10.4 & 11.2 & 81.4 & 85.0 & 64 & 64.4 \\
December & 4.8 & 8.0 & 94.4 & 48.6 & 72.4 & 65.2 \\
January & 2.6 & 5.7 & 96.8 & 56.4 & 72 & 70.5 \\
February & 4.2 & 8.2 & 97.5 & 74.2 & 66.6 & 67.7 \\
March & 8.3 & 13.7 & 111.1 & 47.6 & 61.3 & 55.9 \\
April & 13.7 & 16.8 & 104.7 & 61.6 & 58.2 & 47.6 \\
May & 19.3 & 19.8 & 62.0 & 146.6 & 49.9 & 58.9 \\
Jun & 26.0 & 27.4 & 9.2 & 3.0 & 34.1 & 31.3 \\
Average & 11.91 & 14.36 & -- & -- & 58.76 & 55.12 \\
Total & -- & -- & 706.2 & 528.4 & -- & - \\
\hline
\end{tabular}

*LTA = long-term average (1938-2017)

The soil structure of the trial area where the research is carried out is clayey, has a neutral $\mathrm{pH}$, its lime content is very low, it is salt-free, its $\mathrm{K}$ content is sufficient, in terms of organic matter and phosphorus it is poor (Table 2).

Table 2. Soil analysis values of the experiment area

\begin{tabular}{|c|c|c|c|c|c|c|c|c|c|c|c|c|c|}
\hline pH & $\begin{array}{c}\mathbf{E c} \\
\mathrm{s} / \mathrm{cm}\end{array}$ & $\begin{array}{c}\text { Lime } \\
\mathrm{CaCO}_{3} \\
\%\end{array}$ & $\begin{array}{c}\text { Organic } \\
\text { matter } \\
\%\end{array}$ & $\begin{array}{c}\text { Phosphorus } \\
\mathrm{P}_{2} \mathrm{O}_{5} \\
\mathrm{~kg} / \mathrm{da}\end{array}$ & \begin{tabular}{|c|} 
Potassium \\
$\mathrm{K}_{2} \mathrm{O}$ \\
$\mathbf{k g} / \mathbf{d a}$
\end{tabular} & $\begin{array}{c}\mathbf{F e} \\
\text { ppm }\end{array}$ & $\begin{array}{c}\mathrm{Cu} \\
\mathbf{p p m}\end{array}$ & $\begin{array}{c}\mathbf{Z n} \\
\mathbf{p p m}\end{array}$ & $\begin{array}{c}\text { Mn } \\
\text { ppm }\end{array}$ & $\begin{array}{c}\text { Sand } \\
\%\end{array}$ & $\underset{\%}{\text { Clay }}$ & $\begin{array}{c}\text { Silt } \\
\%\end{array}$ & Texture \\
\hline 6.87 & 602 & 0.64 & 0.90 & 1.67 & 114 & 13.01 & 1.78 & 0.60 & 21.89 & 41.64 & 51.32 & 7.04 & $\mathrm{~L}$ \\
\hline
\end{tabular}




\section{Trial pattern}

The trial consisted of 48 parcels in two separate trials consisting of 24 parcels of $1 \times 5 \mathrm{~m}$ size with 3 replications, with bread and durum wheat according to the randomized block design.

\section{Fertilizer application}

Fertilization has been done to the bacteria untreated parcels as full fertilization with values of $9 \mathrm{~kg} \mathrm{~N} / \mathrm{da}$ and $7 \mathrm{~kg} \mathrm{P}_{2} \mathrm{O}_{5} / \mathrm{da}$; half of these values were applied in $50 \%$ fertilization. In addition, $50 \%$ and $100 \%$ chemical fertilizers were applied without control and fertilization ( $0 \%$ fertilizer). No bacteria were applied to the parcels where the controls were located. The activity of the bacteria was determined according to the controls. All of the phosphorus and $1 / 3$ of the nitrogen were given during planting and diammonium phosphate (18-46-0) was used. The remaining part of the nitrogen was given by urea fertilizer $(46 \% \mathrm{~N})$ during the period of tillering and stalking.

\section{Bacteria application}

In the experiment, within the scope of the TÜBITAK project numbered TOVAG 1080147, nutrient agar (Merck-VM71680604), which was isolated from Van Lake basin and was previously diagnosed with MIS system, was used as a feed-lot for the multiplication of bacteria, PGPB activity of which was exposed to greenhouse and field conditions. $20 \mathrm{~g}$ of nutrient agar was added to one liter of distilled water, adjusted to $\mathrm{pH}$ 7.0, and the mixture was sterilized by autoclave for $15 \mathrm{~min}$ at $121^{\circ} \mathrm{C}$. After sterilization, the feed-lots were cooled to $50{ }^{\circ} \mathrm{C}$, then transferred to petri plates and allowed to solidify. The stock cultures of the bacteria were planted in nutrient agar medium with the help of the needle and incubated at $26 \pm 2{ }^{\circ} \mathrm{C}$ for $24 \mathrm{~h}$ (Fig. 1).
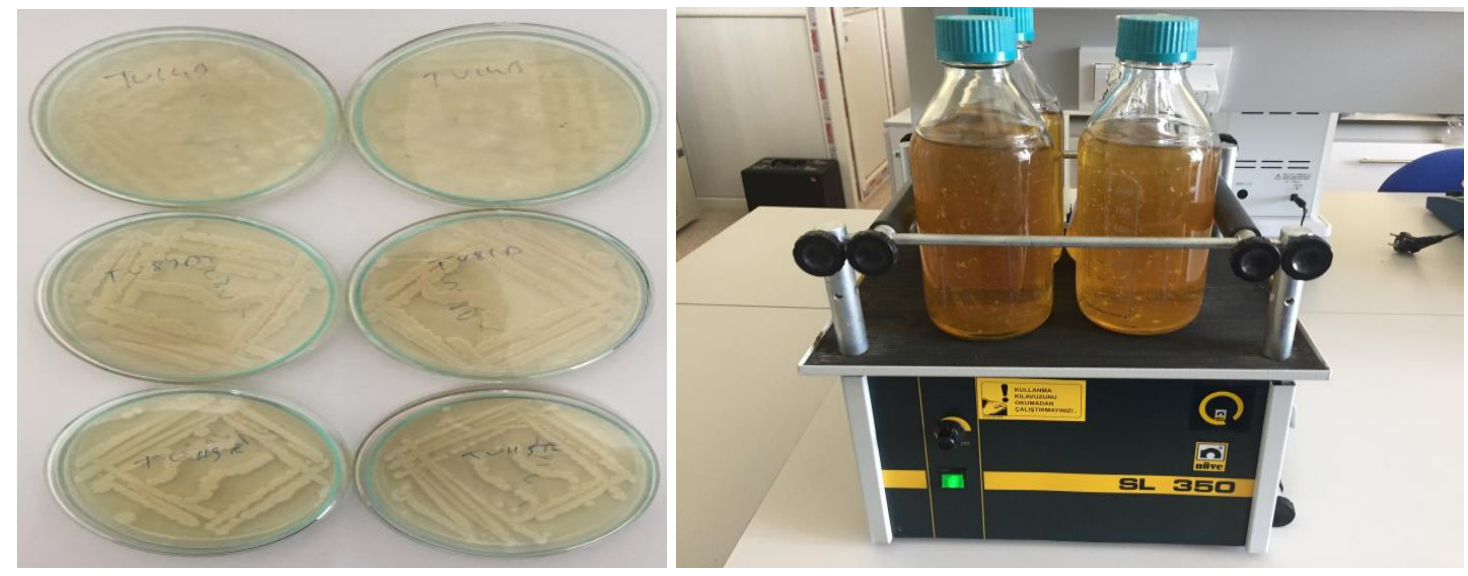

Figure 1. Development of bacteria in nutrient agar and nutrient broth fed-lot

The nutrient broth (Merck-VM775843711) was used as the liquid feed-lot. $8 \mathrm{~g}$ of nutrient broth feed-lot was added to one liter of distilled water and $\mathrm{pH}$ was adjusted to 7.0. The mixture was sterilized by autoclave for $15 \mathrm{~min}$ at $121^{\circ} \mathrm{C}$ and then allowed to cool. A single colony was taken from the bacteria developed in nutrient agar feed-lot and was transferred to nutrient broth feed-lot in aseptic conditions. The bacteria transferred to the liquid feed-lot were incubated at $26 \pm 2{ }^{\circ} \mathrm{C}$ for $24 \mathrm{~h}$ and at $120 \mathrm{rpm}$ in 
the horizontal shaker. After incubation, the bacteria concentrations were turbidimetrically adjusted to $\sim 10^{8} \mathrm{cfu} / \mathrm{ml}$ (Fig. 1). In the final stage, the bacteria were inoculated into the seed. Surface sterilization of the seeds was made with $5 \%(\mathrm{v} / \mathrm{v})$ sodium hypochlorite for $20 \mathrm{~min}$ and washed 3 times with distilled water. Bacteria were applied to the surface sterilized seed for $3 \mathrm{~h}$ in order to allow the swelling of the seed (Clark, 1965). Seeds were laid on drying sheets and allowed to dry. Dried seeds were planted on the field one day later. Sterile nutrient broth feed-lot was used as control.

\section{Planting, care, harvest and threshing}

The experiment was established on the experimental area of Agricultural Faculty of Siirt University in the 2017-2018 production season with three replications according to the randomized block design (Fig. 2).

The size of the parcels is $5 \mathrm{~m}$, the width is $1 \mathrm{~m}$ ( 5 rows and between each row there is $20 \mathrm{~cm}$ ) and each parcel area is $5 \mathrm{~m}^{2}$. Seeds were planted in parcels as 500 seeds per $\mathrm{m}^{2}$. In each parcel, gloves were used to prevent the bacteria from smearing on the seed surface. Experiment was established on 21.11.2017, and the plants sprouted on 01.12.2017 (Fig. 3). Weed control was done by hand. No disease or harmful situation has been observed in the trial area which could cause economic damage.
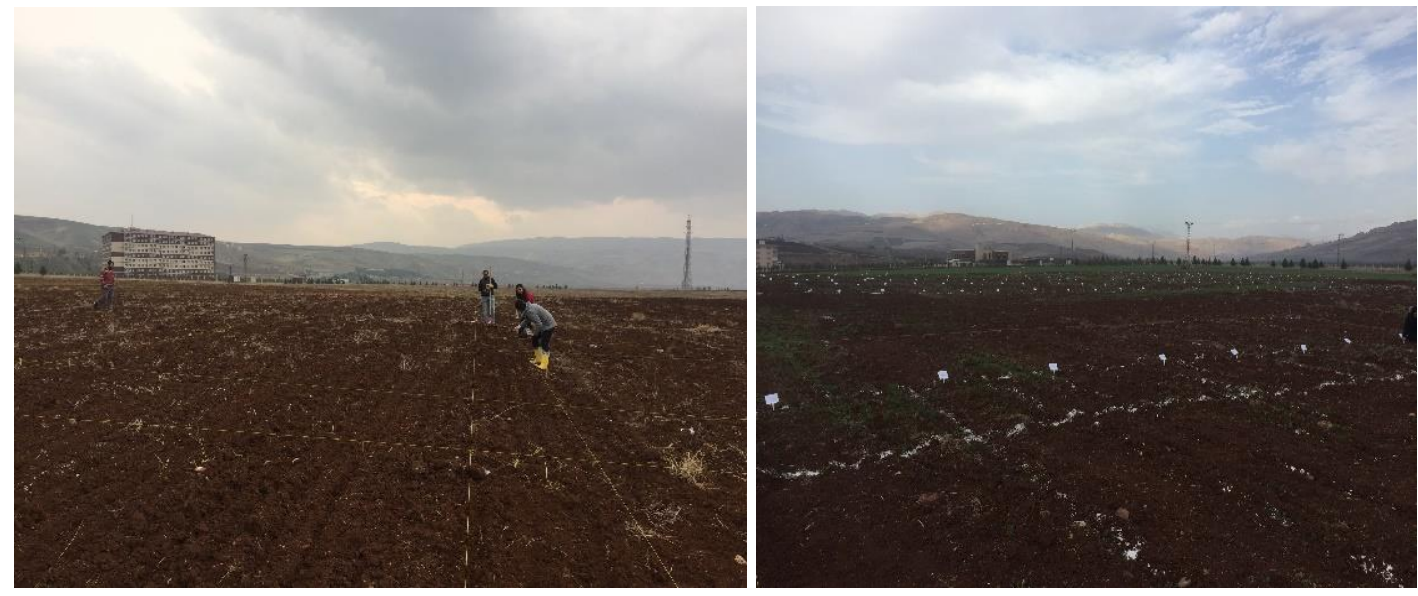

Figure 2. Land parcelling and planting
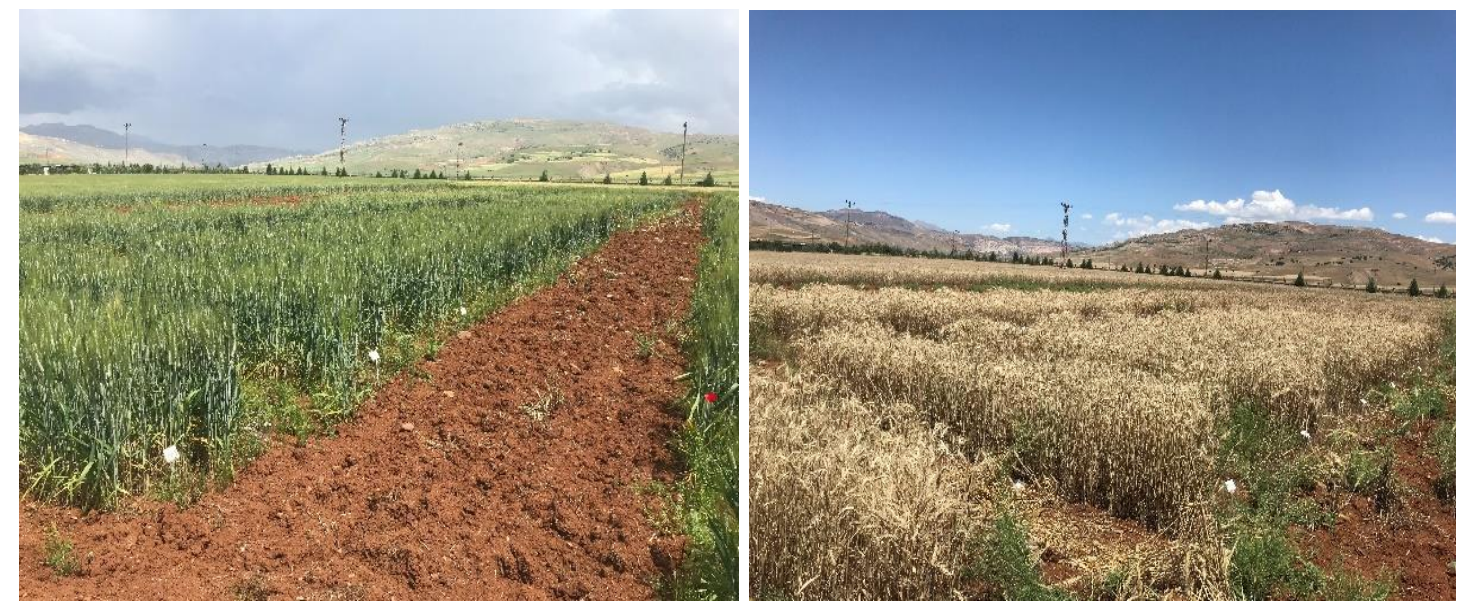

Figure 3. Trial and parcel views 
With the planting process, diammonium phosphate (DAP) was given as $7 \mathrm{~kg}$ phosphorus and $3 \mathrm{~kg}$ nitrogen per decare. According to the results of soil analysis, to meet the nutrients needed by plants; in the period of tillering and bolting, urea was applied in the form of upper fertilization with $3 \mathrm{~kg}$ of pure nitrogen. $9 \mathrm{~kg}$ pure nitrogen and $7 \mathrm{~kg}$ phosphorus were given to the plants during planting, tillering and bolting periods. One row on each side of the parcels and $50 \mathrm{~cm}$ of space at the beginning and end of the parcel were left and the remaining $2.4 \mathrm{~m}^{2}$ area was harvested with the sickle on 01.07.2018. Then it was taken to the warehouse and blended with the machine.

\section{Obtaining data}

The experiment was continued during one growing season. Plant height $(\mathrm{cm})$, spike length $(\mathrm{cm})$, number of tillerings (pcs), number of spikes per square meter $\left(\mathrm{pcs} / \mathrm{m}^{2}\right)$, number of spikelets per spike (number/spike), number of grains per spike (pieces/spike), weight of thousand grams (grams), grain yield $(\mathrm{kg} / \mathrm{da})$, biological yield $(\mathrm{kg} / \mathrm{da})$, hectoliter weight $(\mathrm{kg} / 100 \mathrm{l})$, harvest index $(\%)$ values were determined based on the methods applied in the studies of Tosun et al. (1971) and Ünver (1995).

\section{Statistical evaluation of the results}

The mean values obtained from the data were analyzed using the Statix 10 package program. Grouping of means was done according to Tukey's HSD test.

\section{Results}

\section{Plant height (cm)}

In terms of applications, the highest plant height of Firat-93 durum wheat was obtained from Stenotrophomonas maltophilia (TV14B) with $74.13 \mathrm{~cm}$. and the lowest plant height was obtained from non-inoculated and non-fertilized control with $68.23 \mathrm{~cm}$. Plant sizes in other applications are among these two values (Table 3).

Table 3. Average values of plant height in Furat-93 durum and Ceyhan-99 bread wheat varieties inoculated with different bacterial strains

\begin{tabular}{|c|c|c|}
\hline Application & $\begin{array}{c}\text { Firat-93 } \\
\text { durum wheat }\end{array}$ & $\begin{array}{l}\text { Ceyhan-99 } \\
\text { bread wheat }\end{array}$ \\
\hline Non-inoculated and non-fertilized control & 68.23 & $71.67^{\mathrm{b}}$ \\
\hline $50 \%$ fertilized control & 70.76 & $78.20^{\mathrm{a}}$ \\
\hline $100 \%$ fertilized control & 72.43 & $77.33^{\mathrm{a}}$ \\
\hline Stenotrophomonas maltophilia (TV14B) & 74.13 & $80.07^{\mathrm{a}}$ \\
\hline Bacillus atrophaeus (TV83D) & 73.36 & $78.60^{\mathrm{a}}$ \\
\hline Bacillus-GC Group (TV119E) & 73.71 & $79.47^{\mathrm{a}}$ \\
\hline Cellulomonas turbata (TV54A) & 72.80 & $77.50^{\mathrm{a}}$ \\
\hline Bacillus atrophaeus + Bacillus -GC Group (TV83D+TV119E) & 72.33 & $78.40^{\mathrm{a}}$ \\
\hline Average & 72.22 & 77.65 \\
\hline $\mathbf{P}$ & 0.1002 & 0.0003 \\
\hline Tukey's HSD & 6.4455 & 4.3347 \\
\hline
\end{tabular}

Mean values in columns shown with different letters are significant at $p<0.05$ level according to Tukey's HSD test 
The highest plant height of the Ceyhan-99 bread wheat was obtained from the application of Stenotrophomonas maltophilia (TV14B) with $80.07 \mathrm{~cm}$. and the lowest plant height was obtained as $71.67 \mathrm{~cm}$. from non-inoculated and non-fertilized control. Plant sizes in other applications are among these two values. Plant height in TV14B bacterial application was observed to be $11 \%$ higher than non-inoculated and nonfertilized control. However, in all bacterial applications, the height of the plant was observed to be higher than non-inoculated and non-fertilized control (Table 3).

\section{Spike length}

The highest spike length of the Frrat-93 durum wheat was obtained from BacillusGC Group (TV119E) bacteria with $5.92 \mathrm{~cm}$. and the lowest spike length was obtained from non-inoculated and non-fertilized control as $5.23 \mathrm{~cm}$. Spike length in other applications is among these two values. In addition, it was observed that other bacterial applications had a positive and significant effect on spike size compared to noninoculated and non-fertilized control (Table 4).

Table 4. Average values of spike size in Firat-93 durum and Ceyhan-99 bread wheat varieties inoculated with different bacterial strains

\begin{tabular}{|c|c|c|}
\hline Application & $\begin{array}{c}\text { Firat-93 } \\
\text { durum wheat }\end{array}$ & $\begin{array}{c}\text { Ceyhan-99 } \\
\text { bread wheat }\end{array}$ \\
\hline Non-inoculated and non-fertilized control & $5.23^{b}$ & $6.45^{\mathrm{c}}$ \\
\hline $50 \%$ fertilized control & $5.38^{\mathrm{ab}}$ & $6.94^{\mathrm{bc}}$ \\
\hline $100 \%$ fertilized control & $5.42^{\mathrm{ab}}$ & $6.98^{\mathrm{bc}}$ \\
\hline Stenotrophomonas maltophilia (TV14B) & $5.69^{\mathrm{ab}}$ & $7.90^{\mathrm{a}}$ \\
\hline Bacillus atrophaeus (TV83D) & $5.84^{\mathrm{ab}}$ & $7.22^{\mathrm{ab}}$ \\
\hline Bacillus-GC Group (TV119E) & $5.92^{\mathrm{a}}$ & $7.92^{\mathrm{a}}$ \\
\hline Cellulomonas turbata (TV54A) & $5.86^{\mathrm{ab}}$ & $7.63^{\mathrm{ab}}$ \\
\hline Bacillus atrophaeus + Bacillus -GC Group (TV83D+TV119E) & $5.77^{\mathrm{ab}}$ & $7.37^{\mathrm{ab}}$ \\
\hline Average & 5.64 & 7.30 \\
\hline $\mathbf{P}$ & 0.0126 & 0.0001 \\
\hline Tukey's HSD & 0.6471 & 0.7668 \\
\hline
\end{tabular}

Mean values in columns shown with different letters are significant at $\mathrm{p}<0.05$ level according to Tukey's HSD test

The highest spike length of the Ceyhan-99 bread wheat was obtained from the Bacillus-GC Group (TV119E) bacteria with $7.92 \mathrm{~cm}$. The lowest spike length was obtained from non-inoculated and non-fertilized control with $6.45 \mathrm{~cm}$. Spike length in other applications is among these two values. It has been observed that bacterial applications have a positive and statistically significant effect on the increase of spike length compared to all three controls (Table 4).

\section{Tillering count}

In terms of applications, the highest number of tillerings of Firat-93 durum wheat was obtained from 2.93 to $50 \%$ fertilized control application, while the lowest number of tillerings was obtained by Cellulomonas turbata (TV54A) with 2.52. The number of tillerings in other applications was among these two values. Only Bacillus atrophaeus 
(TV83D) (2.73 count) bacterial application increased in terms of the number of tillerings compared to non-inoculated and non-fertilized control (2.63 count) and other bacterial applications remained below this value (Table 5).

Table 5. Average values of number of tillerings in Firat-93 durum and Ceyhan-99 bread wheat varieties inoculated with different bacterial strains

\begin{tabular}{c|c|c}
\hline Application & $\begin{array}{c}\text { Frrat-93 } \\
\text { durum wheat }\end{array}$ & $\begin{array}{c}\text { Ceyhan-99 } \\
\text { bread wheat }\end{array}$ \\
\hline Non-inoculated and non-fertilized control & 2.63 & 2.07 \\
50\% fertilized control & 2.93 & 2.30 \\
100\% fertilized control & 2.76 & 3.27 \\
Stenotrophomonas maltophilia (TV14B) & 2.57 & 2.07 \\
Bacillus atrophaeus (TV83D) & 2.73 & 2.23 \\
Bacillus-GC Group (TV119E) & 2.60 & 2.50 \\
Cellulomonas turbata (TV54A) & 2.52 & 2.53 \\
Bacillus atrophaeus + Bacillus -GC Group (TV83D+TV119E) & 2.53 & 2.27 \\
Average & 2.66 & 2.40 \\
P & $\mathbf{0 . 7 2 2}$ & $\mathbf{0 . 2 7 4 8}$ \\
Tukey's HSD & 0.8756 & 1.6299 \\
\hline
\end{tabular}

The highest number of tillerings of Ceyhan-99 bread wheat was obtained from the application of $100 \%$ fertilized control with 3.7. The lowest number of tillerings was obtained with 2.07 from non-inoculated and non-fertilized control and Stenotrophomonas maltophilia application (TV14B). The number of tillerings in other applications was among these two values. With the exception of Stenotrophomonas maltophilia (TV14B), there were positive increases in other bacterial applications compared to non-inoculated and non-fertilized control (Table 5).

\section{Number of spikes per square meter}

In terms of applications, the highest number of spikes per square meter that belongs to Frrat-93 durum wheat was obtained as 450 from $50 \%$ fertilized control application. The lowest number of spike number for square meter was obtained from Cellulomonas turbata (TV54A) bacteria application with 291.67. In other applications, the number of spikes per square meter was between these two values. It has been found that bacterial applications generally do not contribute to the increase in the number of spikes per square meter compared to the controls, and that the number of spikes per square meter in all bacterial applications is lower than the general average (369.79) (Table 6).

The highest number of spikes per square meter of Ceyhan-99 bread wheat was obtained as 535.33 from $100 \%$ fertilized control application, while the lowest number of spikes were obtained as 370.00 from non-inoculated and non-fertilized control bacterial application. In other applications, the number of spikes per square meter was between these two values. It has been observed that bacterial applications have more spike numbers per square meters compared to non-inoculated and non-fertilized control. According to the results of the study, the highest number of spikes per square meter was obtained in chemical fertilizer applications (Table 6). 
Table 6. Average values of spike number per square meter in Firat-93 durum and Ceyhan-99 bread wheat varieties inoculated with different bacterial strains

\begin{tabular}{c|c|c}
\hline Application & $\begin{array}{c}\text { Frrat-93 } \\
\text { durum wheat }\end{array}$ & $\begin{array}{c}\text { Ceyhan-99 } \\
\text { bread wheat }\end{array}$ \\
\hline Non-inoculated and non-fertilized control & $360.00^{\mathrm{ab}}$ & 370.00 \\
50\% fertilized control & $450.00^{\mathrm{a}}$ & 483.33 \\
100\% fertilized control & $401.00^{\mathrm{ab}}$ & 535.33 \\
Stenotrophomonas maltophilia (TV14B) & $365.00^{\mathrm{ab}}$ & 421.67 \\
Bacillus atrophaeus (TV83D) & $391.67^{\mathrm{ab}}$ & 456.67 \\
Bacillus-GC Group (TV119E) & $305.00^{\mathrm{ab}}$ & 396.67 \\
Cellulomonas turbata (TV54A) & $291.67^{\mathrm{b}}$ & 386.67 \\
Bacillus atrophaeus + Bacillus -GC Group (TV83D+TV119E) & $393.33^{\mathrm{ab}}$ & 373.33 \\
Average & 369.79 & 427.96 \\
P & $\mathbf{0 . 0 3 3 1}$ & $\mathbf{0 . 1 5 5 4}$ \\
Tukey's HSD & 146.67 & 217.04 \\
\hline
\end{tabular}

Mean values in columns shown with different letters are significant at $p<0.05$ level according to Tukey's HSD test

\section{Spikelet count of the spike}

In terms of applications, the highest number of spikelets that belong to Frrat-93 durum wheat was obtained from Bacillus-GC Group (TV119E) bacteria application with 18.10 and the lowest number of spikelets was obtained as $15.93 \%$ with $50 \%$ Fertilized Control application. In other applications, the number of spikelets was between these two values. However, it was observed that Stenotrophomonas maltophilia (TV14B) and Bacillus atrophaeus (TV83D) bacterial applications did not affect the increase in the number of spikelets (Table 7).

Table 7. Average values of the number of spikelets per spike in Firat-93 durum and Ceyhan99 bread wheat varieties inoculated with different bacterial strains

\begin{tabular}{|c|c|c|}
\hline Application & $\begin{array}{c}\text { Firat-93 } \\
\text { durum wheat }\end{array}$ & $\begin{array}{c}\text { Ceyhan-99 } \\
\text { bread wheat }\end{array}$ \\
\hline Non-inoculated and non-fertilized control & $16.90^{\mathrm{ab}}$ & $14.43^{\mathrm{b}}$ \\
\hline $50 \%$ fertilized control & $15.93^{\mathrm{b}}$ & $15.70^{\mathrm{ab}}$ \\
\hline $100 \%$ fertilized control & $16.77^{\mathrm{b}}$ & $16.97^{\mathrm{ab}}$ \\
\hline Stenotrophomonas maltophilia (TV14B) & $16.53^{\mathrm{b}}$ & $16.83^{\mathrm{ab}}$ \\
\hline Bacillus atrophaeus (TV83D) & $16.83^{b}$ & $16.93^{\mathrm{ab}}$ \\
\hline Bacillus-GC Group (TV119E) & $18.10^{\mathrm{a}}$ & $16.87^{\mathrm{ab}}$ \\
\hline Cellulomonas turbata (TV54A) & $17.07^{\mathrm{ab}}$ & $17.57^{\mathrm{a}}$ \\
\hline Bacillus atrophaeus + Bacillus -GC Group (TV83D+TV119E) & $16.47^{\mathrm{b}}$ & $17.23^{\mathrm{ab}}$ \\
\hline Average & 16.82 & 16.56 \\
\hline $\mathbf{P}$ & 0.0025 & 0.0356 \\
\hline Tukey's HSD & 1.2782 & 2.8926 \\
\hline
\end{tabular}

Mean values in columns shown with different letters are significant at $\mathrm{p}<0.05$ level according to Tukey's HSD test 
In terms of applications, the highest number of spikelets of Ceyhan-99 bread wheat was obtained from Cellulomonas turbata (TV54A) as 17.57 and the lowest number of spikelets was obtained from non-inoculated and non-fertilized control as 14.43. In other applications, the number of spikelets in the spike was between these two values (Table 7).

\section{Grain count of the spike}

In terms of the applications, the highest number of grains per spike for Firat-93 durum wheat is 36.40 with Bacillus-GC Group (TV119E) bacterial application, the lowest number of grains per spike obtained as 27.93 with $50 \%$ Fertilized Control application. The number of grains per spike in other applications was between these two values (Table 8).

Table 8. Average values of the number of grains per spike in Firat-93 durum and Ceyhan-99 bread wheat varieties inoculated with different bacterial strains

\begin{tabular}{|c|c|c|}
\hline Application & $\begin{array}{c}\text { Firat-93 } \\
\text { durum wheat }\end{array}$ & $\begin{array}{c}\text { Ceyhan-99 } \\
\text { bread wheat }\end{array}$ \\
\hline Non-inoculated and non-fertilized control & $28.70^{\mathrm{b}}$ & 25.63 \\
\hline $50 \%$ fertilized control & $27.93^{b}$ & 29.90 \\
\hline $100 \%$ fertilized control & $29.13^{\mathrm{b}}$ & 31.67 \\
\hline Stenotrophomonas maltophilia (TV14B) & $29.10^{\mathrm{b}}$ & 31.06 \\
\hline Bacillus atrophaeus (TV83D) & $29.77^{\mathrm{ab}}$ & 33.03 \\
\hline Bacillus-GC Group (TV119E) & $36.40^{\mathrm{a}}$ & 33.63 \\
\hline Cellulomonas turbata (TV54A) & $30.87^{\mathrm{ab}}$ & 33.33 \\
\hline Bacillus atrophaeus + Bacillus -GC Group (TV83D+TV119E) & $30.47^{\mathrm{ab}}$ & 34.53 \\
\hline Average & 30.29 & 31.60 \\
\hline $\mathbf{P}$ & 0.0264 & 0.1686 \\
\hline Tukey's HSD & 7.2193 & 10.615 \\
\hline
\end{tabular}

Mean values in columns shown with different letters are significant at $\mathrm{p}<0.05$ level according to Tukey's HSD test

The highest number of grains per spike of Ceyhan-99 bread wheat is observed to be 34.54 with Bacillus atrophaeus + Bacillus-GC Group (TV83D + TV119E) bacterial application and the lowest grain number per spike was obtained as 25.63 with noninoculated and non-fertilized control. The number of grains per spike in other applications was between these two values. The data obtained from all bacterial applications were found to be higher on average than the non-fertilized and noninoculated and $50 \%$ fertilized control applications (Table 8).

\section{Thousand grain weight}

In terms of applications, the highest thousand grain weight of Firat-93 durum wheat is obtained from $100 \%$ fertilized control application as $47.99 \mathrm{~g}$. while the lowest thousand grain weight is obtained from Bacillus atrophaeus (TV83D) application as $43.88 \mathrm{~g}$. The weight of one thousand grain in other applications was between these two values (Table 9). 
Table 9. Average values of thousand grain weight in Firat-93 durum and Ceyhan-99 bread wheat varieties inoculated with different bacterial strains

\begin{tabular}{c|c|c}
\hline Application & $\begin{array}{c}\text { Frrat-93 } \\
\text { durum wheat }\end{array}$ & $\begin{array}{c}\text { Ceyhan-99 } \\
\text { bread wheat }\end{array}$ \\
\hline Non-inoculated and non-fertilized control & 46.30 & 38.45 \\
50\% fertilized control & 46.17 & 38.81 \\
100\% fertilized control & 47.99 & 38.45 \\
Stenotrophomonas maltophilia (TV14B) & 45.54 & 40.03 \\
Bacillus atrophaeus (TV83D) & 43.88 & 38.28 \\
Bacillus-GC Group (TV119E) & 45.87 & 39.30 \\
Cellulomonas turbata (TV54A) & 46.46 & 39.42 \\
Bacillus atrophaeus + Bacillus -GC Group (TV83D+TV119E) & 46.80 & 39.60 \\
Average & 46.13 & 39.00 \\
P & $\mathbf{0 . 0 7 0 6}$ & $\mathbf{0 . 0 8 0 6}$ \\
Tukey's HSD & 3.7015 & 2.268 \\
\hline
\end{tabular}

The highest thousand grain weight of the Ceyhan-99 bread wheat was obtained from the application of Stenotrophomonas maltophilia (TV14B) application as $40.03 \mathrm{~g}$. and the lowest thousand grain weight was obtained as $38.28 \mathrm{~g}$. with Bacillus atrophaeus (TV83D) application. One thousand grain weight in other applications is among these two values (Table 9).

\section{Grain yield}

In terms of applications, the highest grain yield of Firat-93 durum wheat was obtained from $100 \%$ fertilized control application as $288.89 \mathrm{~kg} / \mathrm{da}$. The lowest grain yield was obtained from Bacillus atrophaeus + Bacillus-GC Group (TV83D + TV119E) bacteria application as $218.75 \mathrm{~kg} / \mathrm{ha}$.

Table 10. Average values of grain yield in Firat-93 durum and Ceyhan-99 bread wheat varieties inoculated with different bacterial strains

\begin{tabular}{|c|c|c|}
\hline Application & $\begin{array}{c}\text { Firat-93 } \\
\text { durum wheat }\end{array}$ & $\begin{array}{c}\text { Ceyhan-99 } \\
\text { bread wheat }\end{array}$ \\
\hline Non-inoculated and non-fertilized control & 243.06 & $256.95^{\mathrm{c}}$ \\
\hline $50 \%$ fertilized control & 256.25 & $354.17^{\mathrm{ab}}$ \\
\hline $100 \%$ fertilized control & 288.89 & $360.00^{\mathrm{a}}$ \\
\hline Stenotrophomonas maltophilia (TV14B) & 275.69 & $304.08^{\mathrm{abc}}$ \\
\hline Bacillus atrophaeus (TV83D) & 283.33 & $319.45^{\mathrm{abc}}$ \\
\hline Bacillus-GC Group (TV119E) & 229.17 & $285.41^{\mathrm{abc}}$ \\
\hline Cellulomonas turbata (TV54A) & 244.44 & $273.61^{\mathrm{bc}}$ \\
\hline Bacillus atrophaeus + Bacillus -GC Group (TV83D+TV119E) & 218.75 & $274.30^{\mathrm{bc}}$ \\
\hline Average & 254.95 & 303.50 \\
\hline $\mathbf{P}$ & 0.1174 & 0.0052 \\
\hline Tukey's HSD & 89.116 & 85.447 \\
\hline
\end{tabular}

Mean values in columns shown with different letters are significant at $p<0.05$ level according to Tukey's HSD test 
The grain yield in other applications was between these two values. In addition, Bacillus atrophaeus + Bacillus-GC Group (TV83D + TV119E) and Bacillus-GC Group (TV119E) bacterial applications were found to be scarcer and less effective on grain yield compared to the non-inoculated and non-fertilized control. However, yield in Bacillus atrophaeus (TV83D) $(283.33 \mathrm{~kg} / \mathrm{da})$ and Stenotrophomonas maltophilia bacterial applications (TV14B) $(275.69 \mathrm{~kg} / \mathrm{da})$ was found to be close to the full dose fertilizer application (288.89) (Table 10).

The highest grain yield of Ceyhan-99 bread wheat was obtained from $100 \%$ fertilized control as $360.00 \mathrm{~kg} / \mathrm{da}$ and the lowest grain yield was obtained from non-inoculated and non-fertilized control application as $256.95 \mathrm{~kg} / \mathrm{da}$. The grain yield in other applications was between these two values. Bacterial applications were found to contribute to grain yield compared to non-inoculated and non-fertilized control, but the yield was $50 \%$ and $100 \%$ lower than fertilized control. It was observed that Bacillus atrophaeus (TV83D) bacterial application showed a $24 \%$ increase in yield compared to non-inoculated and non-fertilized control (Table 10).

\section{Biological yield}

In terms of applications, the highest biological yield of Firat-93 durum wheat was obtained from Stenotrophomonas maltophilia (TV14B) bacteria as $756.95 \mathrm{~kg} / \mathrm{da}$. The lowest biological yield was obtained from Bacillus atrophaeus + Bacillus -GC Group (TV83D + TV119E) bacterial application as $565.97 \mathrm{~kg} / \mathrm{da}$. Biological yields in other applications are among these two values. Bacillus-GC Group (TV119E) and Cellulomonas turbata (TV54A) bacterial applications were found to have a negative effect on biological yield. It was observed that Stenotrophomonas maltophilia (TV14B) application had the highest biological yield $(756.95 \mathrm{~kg} / \mathrm{da})$ and was found to be more efficient than the yield in full dose fertilizer application $(752.78 \mathrm{~kg} / \mathrm{da})($ Table 11).

Table 11. Average values of biological yield in Firat-93 durum and Ceyhan-99 bread wheat varieties inoculated with different bacterial strains

\begin{tabular}{|c|c|c|}
\hline Application & $\begin{array}{c}\text { Firat-93 } \\
\text { durum wheat }\end{array}$ & $\begin{array}{c}\text { Ceyhan-99 } \\
\text { bread wheat }\end{array}$ \\
\hline Non-inoculated and non-fertilized control & $745.14^{\mathrm{a}}$ & $615.28^{c}$ \\
\hline $50 \%$ fertilized control & $704.17^{\mathrm{ab}}$ & $850.00^{\mathrm{a}}$ \\
\hline $100 \%$ fertilized control & $752.78^{a}$ & $794.00^{\mathrm{ab}}$ \\
\hline Stenotrophomonas maltophilia (TV14B) & $756.95^{\mathrm{a}}$ & $672.92^{\mathrm{bc}}$ \\
\hline Bacillus atrophaeus (TV83D) & $699.66^{\mathrm{ab}}$ & $704.17^{\mathrm{abc}}$ \\
\hline Bacillus-GC Group (TV119E) & $577.78^{\mathrm{b}}$ & $653.47^{\mathrm{bc}}$ \\
\hline Cellulomonasturbata (TV54A) & $627.78^{\mathrm{ab}}$ & $655.56^{\mathrm{bc}}$ \\
\hline Bacillus atrophaeus + Bacillus -GC Group (TV83D+TV119E) & $565.97^{b}$ & $654.86^{\mathrm{bc}}$ \\
\hline Average & 678.78 & 700.09 \\
\hline $\mathbf{p}$ & 0.0017 & 0.0014 \\
\hline Tukey's HSD & 154.21 & 156.68 \\
\hline
\end{tabular}

Mean values in columns shown with different letters are significant at $\mathrm{p}<0.05$ level according to Tukey's HSD test 
The highest biological yield of Ceyhan-99 bread wheat was determined as $850.00 \mathrm{~kg} / \mathrm{da}$ from $50 \%$ fertilized control application and the lowest biological yield was observed as $615.28 \mathrm{~kg} / \mathrm{da}$ from non-inoculated and non-fertilized control application. Biological yields in other applications are among these two values. Bacterial applications were found to contribute to the increase in biological yield compared to non-inoculated and non-fertilized control (Table 11).

\section{Hectoliter weight}

In terms of applications, the highest hectoliter weight of Firat-93 durum wheat was obtained as $77.60 \mathrm{~kg}$ with $50 \%$ fertilized control application, the lowest hectoliter weight was obtained as $74.13 \mathrm{~kg}$ from Bacillus atrophaeus + Bacillus -GC Group (TV83D + TV119E) bacterial application, hectoliter weight in other applications were among these two values. At the same time, according to the full dose fertilizer application $(76.13 \mathrm{~kg})$, Stenotrophomonas maltophilia (TV14B) bacterial application $(77.60 \mathrm{~kg}$ ) was found to be higher but not statistically significant (Table 12).

Table 12. Average values of hectoliter weight in Firat-93 durum and Ceyhan-99 bread wheat varieties inoculated with different bacterial strains

\begin{tabular}{c|c|c}
\hline Application & $\begin{array}{c}\text { Frrat-93 } \\
\text { durum wheat }\end{array}$ & $\begin{array}{c}\text { Ceyhan-99 } \\
\text { bread wheat }\end{array}$ \\
\hline Non-inoculated and NON-FERTILIZED CONTROL & 76.80 & 75.33 \\
50\% fertilized control & 76.00 & 77.47 \\
100\% fertilized control & 76.13 & 74.73 \\
Stenotrophomonas maltophilia (TV14B) & 77.60 & 76.13 \\
Bacillus atrophaeus (TV83D) & 75.47 & 76.53 \\
Bacillus-GC Group (TV119E) & 74.13 & 76.00 \\
Cellulomonas turbata (TV54A) & 75.93 & 76.00 \\
Bacillus atrophaeus + Bacillus -GC Group (TV83D+TV119E) & 74.27 & 77.73 \\
Average & 75.79 & 76.24 \\
P & $\mathbf{0 . 1 2 7 6}$ & $\mathbf{0 . 2 7 2 8}$ \\
Tukey's HSD & 4.14 & 4.1987 \\
\hline \multicolumn{2}{c}{}
\end{tabular}

The highest hectoliter weight of the Ceyhan-99 bread wheat was obtained as $77.73 \mathrm{~g}$. with Bacillus atrophaeus + Bacillus -GC Group (TV83D + TV119E) bacterial application and the lowest hectoliter weight was obtained as $74.13 \mathrm{~g}$. with Stenotrophomonas maltophilia (TV14B) bacterial application. The weight of hectoliter in other applications was between these two values. It was observed that the bacterial application with the highest values, Bacillus atrophaeus + Bacillus -GC Group (TV83D + TV119E) (77.73 kg), was higher than chemical fertilizer applications. In terms of hectoliter weight, which is an important quality parameter, Bacillus atrophaeus + Bacillus-GC Group (TV83D + TV119E) bacterial application having the highest value suggests that bacterial preparations may be an alternative to chemical fertilizer (Table 12). 


\section{Harvest index}

In terms of applications, the highest harvest index of Firat-93 durum wheat was obtained from Bacillus atrophaeus (TV83D) bacterial application as 40.16 and the lowest harvest index was obtained from non-inoculated and non-fertilized control application as 32.91. The harvest index in other applications is among these two values. In general, it was observed that all of the bacterial applications caused a statistically positive and significant increase in the harvest index compared to chemical fertilization (Table 13).

Table 13. Average values of harvest index in Firat-93 durum and Ceyhan-99 bread wheat varieties inoculated with different bacterial strains (\%)

\begin{tabular}{|c|c|c|}
\hline Application & $\begin{array}{c}\text { Firat-93 } \\
\text { durum wheat }\end{array}$ & $\begin{array}{c}\text { Ceyhan-99 } \\
\text { bread wheat }\end{array}$ \\
\hline Non-inoculated and non-fertilized control & 32.91 & 41.70 \\
\hline $50 \%$ fertilized control & 36.54 & 41.79 \\
\hline $100 \%$ fertilized control & 38.48 & 45.08 \\
\hline Stenotrophomonas maltophilia (TV14B) & 36.60 & 45.02 \\
\hline Bacillus atrophaeus (TV83D) & 40.16 & 45.34 \\
\hline Bacillus-GC Group (TV119E) & 39.69 & 43.66 \\
\hline Cellulomonas turbata (TV54A) & 39.25 & 41.94 \\
\hline Bacillus atrophaeus + Bacillus -GC Group (TV83D+TV119E) & 38.71 & 41.95 \\
\hline Average & 37.79 & 43.30 \\
\hline $\mathbf{P}$ & 0.1503 & 0.2919 \\
\hline Tukey’s HSD & 8.65 & 7.0067 \\
\hline
\end{tabular}

The highest harvest index of the Ceyhan-99 bread wheat was obtained from Bacillus atrophaeus (TV83D) bacterial application as $45.34 \%$ and the lowest harvest index was obtained from non-inoculated and non-fertilized control application as $41.70 \%$. The harvest index in other applications is among these two values. The average of bacterial applications was generally higher than non-inoculated and non-fertilized control (Table 13).

\section{Discussion}

Considering the environmental hazards of chemical fertilizers, the fact that plant height values, which are known to increase with nitrogenous fertilizers, do not show a significant difference between the bacterial applications, indicates that the bacterial applications show promising effect. In addition to the fact that no bacterial application studies were performed on wheat before, it was stated that bacterial inoculation related to bacterial growth promotes the nitrogen content and vegetative development of the plant and this increases the plant height. (Şahin et al., 2004; Mukhtar et al., 2017; Kumar et al., 2014; Abbasi et al., 2011; Sultana et al., 2016; Arshadullah et al., 2017). Zafar-ul-Hye et al. (2017) reported that the bacterial applications increased the spike size.

In previous studies, it has been shown that inoculating the seeds in the form of double combination application results in significant increases in yield and yield 
components compared to control (Darmwal and Gaur, 1988; Rai and Gaur, 1988; Şahin et al., 2004). Sood et al. (2018) reported in their study that bacterial application increased the number of tillerings by $28.3 \%$. As a result of our study, it is thought that differentiation of bacterial strains, wheat varieties, climate and soil characteristics may cause in obtaining different findings. According to the results of our research, the highest number of spikes per square meter was obtained in chemical fertilizer applications. It has also been reported by the researchers that nitrogen contributes to healthy plant and spike formation by increasing vegetative growth in the plant and therefore increases the number of spikes per square meter (Millet and Feldman, 1984; Davidson and Chevalier, 1990; Öztürk et al., 2003; Salantur, 2003). Öztürk et al. (2003) investigated the effect of plant growth-promoting bacteria inoculation on wheat and barley yield at various nitrogen fertilization levels. They found that inoculation with Bacillus sp. OSU-142 significantly affected the number of spikelets in wheat spikes but did not have a significant effect on other characters.

It has been reported by many researchers that bacterial inoculation increases the number of grains per spike compared to non-inoculated and non-fertilized control (Öztürk et al., 2003; Salantur, 2003; Sood et al., 2018). In addition, it is said that double and single bacterial inoculation increases the number of grains in the spike (Dokuyucu et al., 1997; Afzal and Bano, 2008; Nain et al., 2010). Bhattarai and Hess (1993) and Das and Saha (2005) reported in their field study that bacterial applications were effective in increasing the thousand grain weight and combined inoculation was more effective than single inoculants. Although there is no similarity between the findings of the cited studies and the findings of the durum wheat variety, some researchers have reported that bacterial applications have a positive effect on the thousand grain weight (Zahir et al., 2009; Mukhtar et al., 2017; Sood et al., 2018). It is thought that this situation is caused by working with different bacteria and varieties.

Many researchers have reported that bacterial inoculation increases grain yield (Barazani and Friedman, 1999; Şahin et al., 2004; Çakmakçı et al., 2005; Çakmakçı et al., 2007; Behera and Rautaray, 2010). In this respect, the results obtained are similar to the previous studies. In previous studies, it has been reported by many researchers that chemical fertilization and bacterial inoculation provide increases in biological yields according to control (Kumar and Ahlawat, 2006; Sultana et al., 2016; Dos Santos et al., 2017; MeCarty et al., 2017; Inwati et al., 2018; Sood et al., 2018). Çığ (2011) reported that bacterial applications do not affect hectoliter. The researcher also stated that the two-bacterial applications cause an increase in the harvest index, but the single bacterial application showed the lowest value.

In terms of the effect of bacteria on varieties; Bacillus-GC groupTV119E bacteria application in durum wheat on spike size, spikelet count, the grain count on the spike has been found to have a statistically significant positive effect. In bread wheat, it was observed that it has a significant positive effect on spike size. Stenotrophomonas maltophilia TV14B (phosphate solubilizing) bacterial application statistically significantly increased the biological yield of durum wheat and plant height in bread wheat varieties. Bacillus atrophaeus TV83D (nitrogen-fixation) bacterial application has been found to have a statistically significant effect on the increase of the biological yield of bread wheat. None of the bacterial applications had statistically significant effect on the number of tillerings, weight of thousand grains, hectoliter weight and harvest index in both varieties. 
All bacterial applications in the bread wheat varieties increased the grain yield statistically significantly compared to the non-inoculated and non-fertilized control. In particular, bacterial application of Bacillus atrophaeus (TV83D) increased yield by $24 \%$ compared to non-inoculated and non-fertilized control. This bacterial strain also yielded an increase on yield in durum wheat, but it was not found to be statistically significant compared to other applications. The fact that durum wheat grain yield $(283.33 \mathrm{~kg} / \mathrm{da})$ is close to $100 \%$ chemical fertilization $(288.89 \mathrm{~kg} / \mathrm{da})$ shows that this bacterium significantly contributes to yield. In addition, the yield of durum wheat varieties in $100 \%$ chemical fertilizer $(288.89 \mathrm{~kg} / \mathrm{da})$ was less than the bread wheat $(360.00 \mathrm{~kg} / \mathrm{da})$. It is believed that this situation may be caused by the fact that the water demand for durum wheat is higher than that of bread wheat and the drought in 2018 spring months has a negative effect on the development of durum wheat.

As a result, bacterial applications significantly increased the yield in bread wheat compared to non-inoculated and non-fertilized control. In addition, it has been determined that bacterial applications show different reactions according to varieties and different bacteria have different effects on plant yield. The highest grain yield increase among microorganism applications was obtained from Bacillus atrophaeus (TV83D) bacterial application. In this respect, it is thought that this bacterial strain can be used as a bio-fertilizer material.

\section{Conclusion}

At the end of the study, mainly Bacillus atrophaeus (TV83D) which has a positive effect on all parameters, Bacillus-GC group TV119E and Stenotrophomonas maltophilia TV14B bacteria strains were found to be promising. However, in order to determine the effectiveness of the bacteria used in the study, it is thought that field trials should be established on different plant species and under different ecological conditions, at least for two years. In addition, in later studies, it is thought that testing of bacterial applications and other organic fertilizers (barn, worm etc.) will contribute to revealing the potential of these bacteria.

Acknowledgements. This study is Ms. thesis and is supported with the project no 2018- SIÜFEB-007 by Siirt University Coordinator of Scientific Research and Projects.

\section{REFERENCES}

[1] Abbasi, M. K., Sharif, S., Kazmi, M., Sultan, T., Aslam, M. (2011): Isolation of plant growth promoting rhizobacteria from wheat rhizosphere and their effect on improving growth, yield and nutrient uptake of plants. - Plant Biosystems 145(1): 159-168.

[2] Afzal, A., Bano, A. (2008): Rhizobium and phosphate solubilizing bacteria improve the yield and phosphorus uptake in wheat (Triticum aestivum). - International Journal of Agriculture and Biology 10(1): 85-88.

[3] Anonymous (2018a): Türkiye Cumhuriyeti Tarım ve Orman Bakanliği GAP Uluslararası Tarımsal Araştırma ve Eğitim Merkezi Müdürlüğ̈̈. https://arastirma.tarim.gov.tr/gaputaem/Belgeler/\%C3\%A7e\%C5\%9Fit\%20belgeleri/t\%C 3\%BCrk\%C3\%A7e/makarnal\%C4\%B1k\%20bu\%C4\%9Fday/f\%C4\%B1rat\%2093.pdf (access date: 11/05/2018). 
[4] Anonymous (2018b): Türkiye Cumhuriyeti Tarım ve Orman Bakanlığı Doğu Akdeniz Tarımsal Araştırma Enstitüsü Müdürlüğü. https://arastirma.tarim.gov.tr/cukurovataem/Menu/25/Bugday-Cesitleri (access date: 11/05/2018).

[5] Anonymous (2018c): Tarım ve Orman Bakanlığı Meteoroloji Genel Müdürlüğ̈̈. - https://mgm.gov.tr/veridegerlendirme/il-ve-ilceleristatistik.aspx?k=Am=SIIRT (access date: 25/05/2018).

[6] Arshadullah, M., Hyder, S. I., Mahmood, I. A., Sultan, T., Naveed, S. (2017): Mitigation of salt stress in wheat plant (Triticum aestivum) by plant growth promoting rhizobacteria for ACC deaminase. - International Journal of Agricultural Research, Sustainability, and Food Sufficiency 4(6): 41-46.

[7] Barazani, O., Friedman, J. (1999): Is IAA major root growth factor secreted from plantgrowth mediating bacteria. - Journal of Chemical Ecology 25(10): 2397-2406.

[8] Bhattarai, T., Hess, D. (1993): Yield responses of Nepalese spring wheat (Triticum aestivum L.) cultivars to inoculation with Azospirillum spp. of Nepalese origin. - Plant and Soil 151(1): 67-76.

[9] Behera, U. K., Rautaray, S. C. (2010): Effect of biofertilizers and chemical fertilizers on productivity and quality parameters of durum wheat (Triticum turgidum) on a vertisol of Central India. - Archives of Agronomy and Soil Science 56(1): 65-72.

[10] Çakmakç1, R. (2009): Promotion of plant growth by ACC deaminase-producing plant growth promoting bacteria under stress conditions (in Turkish). - Atatürk Üniversitesi Ziraat Fakültesi Dergisi 40: 109-125.

[11] Çakmakç1, R., Dönmez, M. F., Canbolat, M., Şahin, F. (2005): The effect of plant growth promoting bacteria on plant growth and soil properties in greenhouse and different field conditions (in Turkish). - Türkiye VI. Tarla Bitkileri Kongresi, 5-9 Eylül 2005, Antalya (Araştırma Sunusu Cilt I, Sayfa 45-50).

[12] Çakmakçı, R., Dönmez, F., Aydın, A., Şahin, F. (2006): Growth promotion of plants by plant growth-promoting rhizobacteria under greenhouse and two different field soil conditions. - Soil Biology Biochemistry 38(6): 1482-1487.

[13] Çakmakçı, R., Erat, M., Erdoğan, Ü., Dönmez, M. F. (2007): The influence of plant growth-promoting rhizobacteria on growth and enzyme activities in wheat and spinach plants. - Journal of Plant Nutrition and Soil Science 170: 288-295.

[14] Çı̆̆g, F. (2011): Effect of microbiological and inorganic fertilization on the yield and yield components in some winter barley (Hordeum vulgare L.) Cultivars. - Doktora Tezi, Yüzüncü Yı1 Üniversitesi, Fen Bilimleri Enstitüsü, Van.

[15] Clarck, D. S. (1965): Method for estimating the bacterial population on surfaces. Canadian Journal of Microbiology 22: 374.

[16] Dal Cortivo, C., Barion, G., Visioli, G., Mattarozzi, M., Mosca, G., Vamerali, T. (2017): Increased root growth and nitrogen accumulation in common wheat following PGPR inoculation: Assessment of plant-microbe interactions by ESEM. - Agriculture, Ecosystems and Environment 247: 396-408.

[17] Darmwal, N. S., Gaur, A. C. (1988): Associative effect of cellulolytic fungi and Azospirillum lipoferum on yeld and nitrogen uptake by wheat. - Plant and Soil 107: 211218.

[18] Das, A. C., Saha, D. (2005): Non-symbiotic nitrogen-fixing bacteria influencing mineral and hydrolysable organic nitrogen in rhizosphere soils of rice (Oryza sativa). - Indian Journal of Agricultural Sciences 75(5): 265-9.

[19] Davidson, D. T., Chevalier, P. M. (1990): Preanthesis tiller mortality in spring wheat. Crop Science 30: 832-836.

[20] Dokuyucu, T., Akkaya, A., Kirtok, Y. (1997): Effect of bacterial inoculation (Azospirillum brasiliense Sp246) on yield components of bread wheat (Triticum aestivum L.) Varieties (in Turkish). - Türkiye II. Tarla Bitkileri Kongresi, 22-25 Eylül 1997, Samsun, pp. 56-60. 
[21] Dos Santos, C. L. R., Alves, G. C., de Matos Macedo, A. V., Giori, F. G., Pereira, W., Urquiaga, S., Reis, V. M. (2017): Contribution of a mixed inoculant containing strains of Burkholderia sp. and Herbaspirillum sp. to the growth of three sorghum genotypes under increased nitrogen fertilization levels. - Applied Soil Ecology 113: 96-106.

[22] Elçi, Ş., Kolsarıcı, Ö., Geçit, H. (1994): Field Crops (Second Ed.). - Ankara Üniversitesi Ziraat Fakültesi, Ankara.

[23] Erman, M., Kotan, R., Çakmakçı, R., Çı̆̆, F., Karagöz, K., Sezen, M. (2010): Effect of nitrogen fixing and phosphate-solubilizing rhizobacteria isolated from Van Lake Basin on the growth and quality properties in wheat and sugar beet. - Turkey IV. Organic Farming Symposium, 28 June-1 July, Erzurum, Turkey, pp. 325-329.

[24] Gustafson, P., Raskina, O., Ma, X., Nevo, E. (2009): Wheat Evolution, Domestication, and Improvement. - In: Carver, B. F. Wheat Science and Trade. Wiley-Blackwell, Iowa, pp. 5-67.

[25] Hussain, M., Asgher, Z., Tahir, M., Ijaz, M., Shahid, M., Ali, H., Sattar, A. (2016): Bacteria in combination with fertilizers improve growth, productivity and net returns of wheat (Triticum aestivum L.). - Pakistan Journal of Agricultural Sciences 53(3): 633-645.

[26] Inwati, D. K., Yadav, J., Yadav, J. S. (2018): Effect of different levels, sources and methods of application of nitrogen on growth and yield of wheat (Triticum aestivum L.). - International Journal of Current Microbiology and Applied Sciences 7(2): 2398-2407.

[27] Kumar, A., Maurya, B. R., Raghuwanshi, R. (2014): Isolation and characterization of PGPR and their effect on growth, yield and nutrient content in wheat (Triticum aestivum L.). - Biocatalysis and Agricultural Biotechnology 3(4): 121-128.

[28] Kumar, V., Ahlawat, I. P. S. (2006): Effect of biofertilizer and nitrogen on wheat (Triticum aestivum) and their after effects on succeeding maize (Zea mays) in wheatmaize cropping system. - Indian Journal of Agricultural Science 76(8): 465-468.

[29] Laloo, B., Rai, P. K., Ramteke, P. W. (2017): Effect of PGPR on improving the germination of durum wheat (Triticum durum Desf.) under $\mathrm{pH}$ stress condition. International Journal of Current Microbiology and Applied Sciences 6(12): 4294-4302.

[30] MeCarty, S., Chauhan, D., MeCarty, A., Tripathi, K., Selvan, T., Dubey, S. (2017): Effect of azotobacter and phosphobacteria on yield of wheat (Triticum aestivum. - Vegetos - An International Journal of Plant Research 30(2): 13.

[31] Meena, P., Rai, A. (2017): Effect of PGPR on morphological properties of different varieties of wheat (Triticum aestivum). - The Pharma Innovation 6(7): 271-277.

[32] Mehnaz, S., Mirza, M. S., Haurat, J., Bally, R., Normand, P., Bano, A., Malik, K. A. (2001): Isolation and 16S rRNA sequence analysis of the beneficial bacteria from the rhizosphere of rice. - Canadian Journal of Microbiology 47: 110-117.

[33] Mehnaz, S., Baig, D. N., Lazarovits, G. (2010): Genetic and phenotypic diversity of plant growth promoting rhizobacteria isolated from sugarcane plants growing in Pakistan. Journal Microbiology Biotechnology 20: 1614-1623.

[34] Millet, E., Feldman, M. (1984): Yield response of a common spring wheat cultivar to inoculation with Azospirillum brasilense at various levels of nitrogen fertilization. - Plant and Soil 80(2): 255-259.

[35] Mukhtar, S., Shahid, I., Mehnaz, S., Malik, K. A. (2017): Assessment of two carrier materials for phosphate solubilizing biofertilizers and their effect on growth of wheat (Triticum aestivum L.) - Microbiological Research 205: 107-117.

[36] Nain, L., Rana, A., Joshi, M., Jadhav, S. D., Kumar, D., Shivay, Y. S., Paul, S., Prasanna, R. (2010): Evaluation of synergistic effects of bacterial and cyanobacterial strains as biofertilizers for wheat. - Plant Soil 331: 217-230.

[37] Naveed, M., Zahir, Z. A., Khalid, M., Asghar, H. N., Akhtar, M. J., Arshad, M. (2008): Rhizobacteria containing ACC-deaminase for improving growth and yield of wheat under fertilized conditions. - Pakistan Journal of Botany 40(3): 1231-1241. 
[38] Öztürk, A., Çağlar, Ö., Şahin, F. (2003). Yield response of wheat and barley to inoculation of plant growth promoting rhizobacteria at various levels of nitrogen fertilization. - Journal of Plant Nutrition and Soil Science 166: 262-266.

[39] Rai, S. N., Gaur, A. C. (1988): Characterization of Azotobacter ssp. and effect of Azotobacter and Azospirillum as inoculant on the yield and n-uptake of wheat crop. Plant and Soil 109: 131-134.

[40] Rana, A., Saharan, B., Joshi, M., Prasanna, R., Kumar, K., Nain, L. (2011): Identification of multi-trait PGPR isolates and evaluating their potential as inoculants for wheat. Annals of Microbiology 61(4): 893-900.

[41] Şahin, F., Çakmakçı, R., Kantar, F. (2004): Sugar beet and barley yields in relation to inoculation with N2-fixing and phosphate solubilizing bacteria. - Plant Soil 265: 123129.

[42] Salantur, A. (2003): Effects of bacteria strains isolated from cereal growing areas of Erzurum and Pasinler valleys on the growth and development of wheat and barley (in Turkish). - Atatürk Üniversitesi Fen Bilimleri Enstitüsü, Erzurum.

[43] Sood, G., Kaushal, R., Chauhan, A., Gupta, S. (2018): Indigenous plant-growthpromoting rhizobacteria and chemical fertilisers: Impact on wheat (Triticum aestivum) productivity and soil properties in North Western Himalayan region. - Crop and Pasture Science 69(5): 460-468.

[44] Sultana, U., Suseelendra, D., Gopal, R. (2016): Successful colonization of roots and plant growth promotion of sorghum (Sorghum bicolor L.) by seed treatment with Pseudomonas putida and Azotobacter chroococcum. - World 3(1): 043-049.

[45] Tahir, M., Khalid, U., Ijaz, M., Shah, G. M., Naeem, M. A., Shahid, M., Kareem, F. (2018): Combined application of bio-organic phosphate and phosphorus solubilizing bacteria (Bacillus strain MWT 14) improve the performance of bread wheat with low fertilizer input under an arid climate. - Brazilian Journal of Microbiology 49(1): 15-24.

[46] Tosun, O., Genç, İ., Yurtman, N. (1971): Effects of commercial fertilizers on germination and propagation of wheat (in Turkish). - A. Ü. Ziraat Fakültesi Yıllığı 3-4: 283-299.

[47] Tozlu, E., Karagöz, K., Babagil, G., Dizikısa, T., Kotan, R. (2014): Bitki büyümesini teşvik eden bazı bakterilerin kuru fasulyenin (Phaseolus vulgaris L. cv. Aras 98) verim ve verim unsurlarına etkisi. - Atatürk Üniversitesi Ziraat Fakültesi Dergisi 43(2): 101 106.

[48] Ünver, S. (1995): The effect of seed grown on yield and yield components of wheat (in Turkish). - Tarım Dergisi 1995: 1-37.

[49] Zabihi, H. R., Savaghebi, G. R., Khavazi, K., Ganjali, A., Miransari, M. (2011): Pseudomonas bacteria and phosphorous fertilization, affecting wheat (Triticum aestivum L.) yield and $\mathrm{P}$ uptake under greenhouse and field conditions. - Acta Physiologiae Plantarum 33(1): 145-152.

[50] Zafar-ul-Hye, M., Aslam, U., Muqaddas, B., Hussain, M. B. (2017): Connotation of Enterobacter cloacae-W6 and Serratia ficaria-W10 with or without carriers for improving growth, yield and nutrition of wheat. - Soil and Environment 36(2): 182-189.

[51] Zahir, Z. A., Ghani, U., Naveed, M., Nadeem, S. M., Asghar, H. N. (2009): Comparative effectiveness of Pseudomonas and Serratia sp. containing ACC-deaminase for improving growth and yield of wheat (Triticum aestivum L.) under salt-stressed conditions. Archives of Microbiology 191(5): 415-424.

[52] Zohary, D., Hopf, M. (2000): Domestication of Plants in the Old World. 3rd Ed. Clarendon Press, Oxford, UK. 